\title{
Metal enrichment and lead isotope analysis for source apportionment in the
}

\section{urban dust and rural surface soil}

\author{
Yang $\mathrm{Yu}^{1,2}$, Yingxia $\mathrm{Li}^{1 *}$, Ben $\mathrm{Li}^{2}$, Zhenyao Shen ${ }^{1}$, Michael K. Stenstrom²
}

1. State Key Laboratory of Water Environment Simulation, School of Environment, Beijing Normal University, Beijing 100875, China

2. Department of Civil and Environmental Engineering, University of California Los Angeles, Los Angeles, CA 90095, USA

* Corresponding author: Yingxia Li

Email: yingxia@bnu.edu.cn

Tel: 86-10-58800260

Fax: 86-10-58800260

\section{Abstract:}

To understand the metal accumulation in the environment and identify its sources, 29 different metal contents and lead $(\mathrm{Pb})$ isotope ratios were determined for 40 urban dust samples, 36 surface soil samples, and one river sediment sample collected in the municipality of Beijing, China. Results showed that cadmium, copper $(\mathrm{Cu})$, mercury, $\mathrm{Pb}$, antimony $(\mathrm{Sb})$, and zinc demonstrated to be the typical urban contaminants and mostly influenced by the adjacent human activities with higher content to background ratios and SD values. Among the 29 metal elements investigated, $\mathrm{Cu}$ and $\mathrm{Sb}$ were found to be the most distinct elements that were highly affected by the developing level and congestion status of the cities with much higher contents in dust in more developed and congested cities. There was a relatively wider range of $\mathrm{Pb}$ isotope ratios of country surface soil than those of urban dust. The results of source identification based on $\mathrm{Pb}$ isotope ratios showed that coal combustion was the first largest $\mathrm{Pb}$ source and vehicle exhaust was the second largest source. The sum of them accounted for $74.6 \%$ mass proportion of overall $\mathrm{Pb}$ pollution on average. The surface soil sample collected at an iron mine had the highest ${ }^{204} \mathrm{~Pb} /{ }^{206} \mathrm{~Pb}$, ${ }^{207} \mathrm{~Pb} /{ }^{206} \mathrm{~Pb}$, and ${ }^{208} \mathrm{~Pb} /{ }^{206} \mathrm{~Pb}$ ratios indicating ore had much higher ratios than other sources. The fine particle subsamples had higher ${ }^{204} \mathrm{~Pb} /{ }^{206} \mathrm{~Pb},{ }^{207} \mathrm{~Pb} /{ }^{206} \mathrm{~Pb}$, and ${ }^{208} \mathrm{~Pb} /{ }^{206} \mathrm{~Pb}$ ratios than the coarse 
particle subsamples indicating more anthropogenic sources of coal combustion and vehicle exhaust for fine particles and more background influence for coarse particles. These results help with pinpointing the major $\mathrm{Pb}$ sources and applying suitable measures for the target sources.

Capsule abstract: Metal enrichment level and sources varied for different developing areas in the same municipality and $\mathrm{Pb}$ isotope ratios indicated that coal and vehicle exhaust are the main $\mathrm{Pb}$ sources.

Keywords: urban dust, rural surface soil, metal, $\mathrm{Pb}$ isotope, Beijing

\section{Introduction}

Urban dust and rural surface soils are good indictors of the accumulation of metal contamination from human activities (Sezgin et al., 2004; Christoforidis and Stamatis, 2009; Acosta et al., 2015; Song et al., 2015). Both are mobile and can be easily suspended by wind or transported in stormwater runoff (Davis et al., 2001; Lau et al., 2009; Egodawatta et al., 2013). High metal contents are often found in environmental media because of the rapid industrialization and urbanization (Li et al., 2013; Lu et al., 2014; Madarang and Kang, 2014). Human exposure to metal pollutants in urban dust and rural surface soil through inhalation, direct ingestion, and dermal contact can adversely affect human health (Granero and Domingo, 2002). Most metals will harm human internal organs if the safe dose levels are exceeded but this is especially the case for some toxic metals such as lead $(\mathrm{Pb})$, chromium $(\mathrm{Cr})$, and cadmium $(\mathrm{Cd})$, which are often known as "chemical time bombs" (Stigliani et al., 1991). Tracing the sources of heavy metals in urban dust and rural surface soil is of key importance for our understanding of their behavior and to control the exposure risk (Žibret, 2012).

Sources of various metals in urban environments are numerous and often difficult to identify. 
Statistical analyses, such as principal component analysis, clustering analysis, and multivariate statistical analysis, were popularly used to identify the sources and pathways of heavy metal contamination (Franco-Uría et al., 2009; Lu et al., 2010; Zhao and Li, 2013). These methods are easy to use, but usually provide only general information on the sources. Isotopic fingerprinting, which is based on the ratios of stable isotopes, is a more in-depth method used to identify the origins of various contaminants (Díaz-Somoano et al., 2009; Gao et al., 2013). Stable isotopes of carbon, oxygen, $\mathrm{Pb}$, and other metals have frequently been used to identify the sources.

There are four naturally occurring $\mathrm{Pb}$ stable isotopes $\left({ }^{204} \mathrm{~Pb},{ }^{206} \mathrm{~Pb},{ }^{207} \mathrm{~Pb},{ }^{208} \mathrm{~Pb}\right)$. Their abundance extensively varies because of different decay pathways from ${ }^{238} \mathrm{U},{ }^{235} \mathrm{U}$ and ${ }^{232} \mathrm{Th}$ to ${ }^{206} \mathrm{~Pb},{ }^{207} \mathrm{~Pb},{ }^{208} \mathrm{~Pb}$, respectively (Faure, 1986). Different types of ore deposits and anthropogenic sources have their distinct isotopic ratios or signatures (Cheng and $\mathrm{Hu}, 2010$ ). The $\mathrm{Pb}$ isotope ratio did not change in industrial or environmental processing, and retained its characteristic ratio from its source ore (Ault et al., 1970). The Pb isotope ratios can be used to identify the sources and transport pathways of $\mathrm{Pb}$ in pollution studies (Hu et al., 2014; Liu et al., 2014; Han et al., 2015).

Certain studies have shown that the qualitative analysis based on the $\mathrm{Pb}$ isotope ratios have been well performed in many study areas (Zhu et al., 2013; Hu et al., 2014; Hu et al., 2015a). The $\mathrm{Pb}$ isotope ratios were determined for various environmental media including organisms, atmospheric aerosol, soil, urban dust, sediment and so on (Ip et al., 2005; Widory et al., 2010; Zhu et al., 2013; Hu et al., 2015b). At the same time, the $\mathrm{Pb}$ isotope ratios of pollution sources were also investigated such as coal combustion, mining, industrial emissions, vehicle exhaust (Bi et al., 2013; Liu et al., 2014; Hu et al., 2014). Normally Pb isotope was used to pinpoint the sources of $\mathrm{Pb}$ poisoning based on comparing the $\mathrm{Pb}$ isotope ratios of samples with those of possible sources. 
For quantitative calculation, more work should be done to promote this method.

The objectives of this study are (1) to analyze the contents of 29 different metals and their spatial distributions in urban dust and rural surface soil; (2) to characterize the $\mathrm{Pb}$ isotope ratios of urban dust and rural surface soil from different development areas; (3) to calculate the contribution from different $\mathrm{Pb}$-related sources through $\mathrm{Pb}$ isotope ratios. The research results are expected to help environmental scientists and regulators to better understand the behavior of metals in soils and dusts of different developing areas and to manage the human and environmental exposure risks.

\section{Materials and methods}

\subsection{Study sites}

The municipality of Beijing is a typically well-developed region in northern China, which includes six central urban districts and ten developing districts with 142 towns and large county areas (Beijing Statistics Bureau, 2013). Fig. 1 shows the three sampling areas with 77 sampling sites representing different development status of the municipality of Beijing: Beijing center (BJC, central urban) located in the central urban districts, Miyun Town (MYT, town) in the developing districts, and Miyun County (MYC, rural county) located in the rural area of the developing districts. The BJC is a densely populated area with a population density of 8,972 persons $/ \mathrm{km}^{2}$, while MYT is a small town that is less densely populated and MYC is a rural area composed primarily of agricultural land, grasslands, and mountains with a population density of 213 persons $/ \mathrm{km}^{2}$ (Beijing Statistics Bureau, 2013). Overall, 40 surface dust and 36 surface soil samples were collected from urban area (BJC and MYT) and rural area (MYC), respectively, as the representative media containing typical pollutions from human activities in different 
developing level areas. Considering surface soils and dust could contribute particle matter and pollutants to the hydrosphere when it rains, one sediment sample was collected to compare with surface dust and soil samples.

Fig. 1 Sampling locations in Beijing center (BJC), Miyun Town (MYT), and Miyun County (MYC), China.

\subsection{Sampling}

A total of 30 urban dust samples were collected from BJC in September and October 2012; a total of 10 urban dust samples were collected in MYT in January 2013; a total of 36 surface soil samples were collected from Sites 1 to 36 in December 2012 over the entire MYC area. In addition, one surface sediment sample was collected from Site 37 in the Baihe River in December 2012. Detailed information about the sampling sites is contained in Supplementary Table S1.

The sampling method for the urban dust and rural surface soil was described in our previous study (Li et al., 2016). Subsamples taken from Sites 14 and 28 in BJC were sieved through a 120 $\mu \mathrm{m}$ opening nylon sieve to produce large and small fractions (BJC14a: particle diameter $>120 \mu \mathrm{m}$, BJC14b: particle diameter $<120 \mu \mathrm{m}$; BJC28a: particle diameter $>120 \mu \mathrm{m}$ and BJC28b: particle diameter $<120 \mu \mathrm{m})$. These fractions were used to analyze the difference in metal contents between different particle sizes.

One surface sediment sample was collected in December, 2012 from Site 37 in the Baihe River, which was upstream of the Miyun Reservoir. The surface sediment sample was collected from the river bottom using a stainless steel shovel and deposited into a self-sealing plastic bag. The surface sediment sample was air dried for one month and extraneous matter such as leaves and large stones were removed. 


\subsection{Analysis of metal contents}

All air-dried dust, soil, and sediment samples (including the subsamples of BJC14 and BJC28) were ground into particles less than $200 \mu \mathrm{m}$ in diameter and stored at $4{ }^{\circ} \mathrm{C}$ before analysis. Approximately $0.5 \mathrm{~g}$ of the ground sample powder was digested using hydrofluoric acid, nitric acid, perchloric acid and aqua regia according to the national standard method for China (GB, 1995). Then the contents of $\mathrm{Cd}$, cerium (Ce), cobalt (Co), copper (Cu), lanthanum (La), molybdenum (Mo), niobium ( $\mathrm{Nb}$ ), neodymium ( $\mathrm{Nd}$ ), nickel (Ni), $\mathrm{Pb}$, scandium ( $\mathrm{Sc}$ ), thallium ( $\mathrm{Tl}$ ), yttrium $(\mathrm{Y})$, and zinc $(\mathrm{Zn})$ were determined by inductively coupled plasma-mass spectrometry (ICP-MS). In addition, the contents of barium $(\mathrm{Ba}), \mathrm{Cr}$, manganese $(\mathrm{Mn})$, rubidium $(\mathrm{Rb})$, strontium $(\mathrm{Sr})$, titanium $(\mathrm{Ti})$, aluminium $(\mathrm{Al})$, ferric $(\mathrm{Fe})$, magnesium $(\mathrm{Mg})$, calcium $(\mathrm{Ca})$, sodium (Na), and kalium (K) were determined by inductively coupled plasma-optical emission spectrometer (ICP-OES). In order to get the contents of arsenic (As), antimony (Sb) and mercury $(\mathrm{Hg})$, aqua regia, potassium permanganate and oxalate were used to digest the ground sample powder. Then As and Sb contents were determined using hydride generation-atomic fluorescence spectrometry (HG-AFS). The content of $\mathrm{Hg}$ was determined using cold vapor generation-atomic fluorescence spectrometry (CV-AFS).

The limits of detection for $\mathrm{As}, \mathrm{Ce}, \mathrm{Co}, \mathrm{Cu}, \mathrm{La}, \mathrm{Sc}$, and $\mathrm{Y}$ were $1 \mu \mathrm{g} / \mathrm{g}$. The limits of detection for $\mathrm{Nb}, \mathrm{Ni}, \mathrm{Pb}$, and $\mathrm{Zn}$ was $2 \mu \mathrm{g} / \mathrm{g}$. The limits of detection for $\mathrm{Ba}, \mathrm{Cr}, \mathrm{Rb}$, and $\mathrm{Sr}$ were $5 \mu \mathrm{g} / \mathrm{g}$. The limits of detection for $\mathrm{Mn}, \mathrm{Ti}, \mathrm{Mo}, \mathrm{Tl}, \mathrm{Sb}$, and $\mathrm{Cd}$ were $10,10,0.2,0.1,0.05$, and $0.02 \mu \mathrm{g} / \mathrm{g}$, respectively. The limit of detection for $\mathrm{Hg}$ was $2 \mathrm{ng} / \mathrm{g}$. The limits of detection for $\mathrm{Al}$ and $\mathrm{Fe}$ were $0.1 \%$ and the detection limit for $\mathrm{Mg}, \mathrm{Ca}, \mathrm{Na}$, and $\mathrm{K}$ was $0.05 \%$, respectively. Duplicate samples (one duplicate every 10 samples) were measured for data quality assurance. The recovery rate was 
obtained from adding geochemical reference materials (e.g., GSS17, GSS25, GSS26, and GSS27) (one every 10 samples) and calculated to be the ratio of the determined value and reference value of the reference material. The recovery rate ranged from $80.3 \%$ to $122.4 \%$.

\subsection{Pb isotope analysis}

A total of 38 dust samples from BJC and MYT, excluding BJC14 and BJC28, were chosen for $\mathrm{Pb}$ isotope analysis. The $\mathrm{Pb}$ isotopes of the four subsamples $\mathrm{BJC} 14 \mathrm{a}, \mathrm{BJC} 14 \mathrm{~b}, \mathrm{BJC} 28 \mathrm{a}$, and BJC28b were also analyzed. For MYC, we analyzed a total of 20 soil samples and one sediment sample. Locations of the $\mathrm{Pb}$ isotope analyses are shown with red stars in Fig. 1.

The air-dried dust, soil, and sediment samples were ground into particles less than $74 \mu \mathrm{m}$ particle diameter ( $200 \mathrm{mesh})$. The samples were then heated at $550^{\circ} \mathrm{C}$ for half an hour in a muffle furnace to destroy the organic matter in the samples. The samples were sequentially digested with $\mathrm{HNO}_{3}-\mathrm{HF}-\mathrm{HCl}-\mathrm{HBr}$ in a Teflon beaker. The extracted samples were purified and then ${ }^{206} \mathrm{~Pb} /{ }^{204} \mathrm{~Pb}$, ${ }^{207} \mathrm{~Pb} /{ }^{204} \mathrm{~Pb},{ }^{208} \mathrm{~Pb} / 204 \mathrm{~Pb},{ }^{208} \mathrm{~Pb} / 206 \mathrm{~Pb}$, and ${ }^{207} \mathrm{~Pb} /{ }^{206} \mathrm{~Pb}$ analyses were carried out on a MicroMass Isoprobe multi-collector inductively coupled plasma mass spectrometer at the Guangzhou Institute of Geochemistry, Chinese Academy of Sciences. Every sample test consisted of 100 cycles and the mean value of 100 cycles was used as the isotope value.

Thallium as an internal control was used to correct $\mathrm{Pb}$ mass fractionation, which greatly improved the reproducibility of the isotope analysis. The $\mathrm{Pb}$ isotopic ratios reported in this work were corrected using standard reference material (SRM981, National Institute of Standards and Technology, NIST, USA). The NIST SRM 981 was run after every five samples separately to compensate for any mass bias and to assess precision. BCR-2 and JB-3, reference materials from the United States Geological Survey (USGS) and Geological Survey of Japan (GSJ), respectively, 
were measured with the samples to examine $\mathrm{Pb}$ isotope experimental process accuracy. The results of BCR-2 and JB-3 were all within the reference range, which demonstrated little $\mathrm{Pb}$ pollution during the experimental process. $\mathrm{Pb}$ isotope ratio results were reliable.

\subsection{Data analysis}

Descriptive statistical analyses were performed by the Microsoft Excel 2010, Matlab R2010b ArcGIS 10.0, Origin 8.0 and SPSS19.0. Fig.1 and Fig.3 were drawn through ArcGIS 10.0. Fig.2 and Fig.4 were performed by Origin 8.0.

Inverse distance weighting (IDW) is an interpolation method widely applied to elucidate spatial distribution of many parameters. IDW assumes that the predictions are a linear combination of available data, which are weighted according to their distance from the point of being interpolated. Studies showed that distribution of metal elements had similar characteristics to IDW's assumption (Gu et al., 2012), IDW interpolation with power of 2 and the neighboring samples of 12 was applied to visualize the spatial distribution of metal contents in urban dust and rural surface soil using ArcGIS 10.0.

\section{Results and discussion}

\subsection{Metal enrichment in urban dust and rural surface soil}

The descriptive statistics of the 29 metal elements in the 76 samples from the three study areas, together with the background values, are shown in Table 1. Metal contents had a large range from $0.02 \mu \mathrm{g} / \mathrm{g}$ ( $\mathrm{Hg}$ in MYC) to $11,067 \mu \mathrm{g} / \mathrm{g}$ ( $\mathrm{Ti}$ in MYC) owing to the various enrichments in the natural environment and the different emission intensities from human activities. Standard deviation $(\mathrm{SD})$ values of $\mathrm{Cd}, \mathrm{Cu}, \mathrm{Hg}, \mathrm{Mo}, \mathrm{Pb}, \mathrm{Sb}$, and $\mathrm{Zn}$ are more than half of the corresponding 
mean values, which are shaded in Table 1 . The SD values of the other metals are all less than half of the corresponding mean values. Results showed that these metals have relatively different contents at different locations and thus might have different emission sources. Human activities should be the major source of these metals, except Mo, which has a content of below the background value in most samples.

Table 1 Descriptive statistics of metal contents in urban dust and rural surface soil samples.

Ratios between individual element contents and the background values were calculated for each sample and the mean and maximum values are shown in Fig. 2. There are few anthropogenic emissions and accumulations for $\mathrm{As}, \mathrm{Ce}, \mathrm{Co}, \mathrm{La}, \mathrm{Mn}, \mathrm{Mo}, \mathrm{Nd}, \mathrm{Ni}, \mathrm{Rb}, \mathrm{Sc}, \mathrm{Ti}, \mathrm{Tl}, \mathrm{Y}, \mathrm{Al}$, and $\mathrm{K}$ in the study area with ratios close to or less than 1. Clearly identifiable human activity emissions and influences were demonstrated by larger ratios ranging from 1 to 2 for $\mathrm{Ba}, \mathrm{Cr}, \mathrm{Nb}, \mathrm{Sr}, \mathrm{Fe}, \mathrm{Mg}$ and $\mathrm{Na}$ and higher than 2 for $\mathrm{Cd}, \mathrm{Cu}, \mathrm{Hg}, \mathrm{Pb}, \mathrm{Sb}, \mathrm{Zn}$, and $\mathrm{Ca}$. The contents of $\mathrm{Ba}, \mathrm{Cd}, \mathrm{Cr}, \mathrm{Cu}, \mathrm{Hg}, \mathrm{Pb}$, $\mathrm{Sb}, \mathrm{Sr}, \mathrm{Zn}, \mathrm{Ca}$ and $\mathrm{Mg}$ in urban dust from BJC and MYT were higher than those from MYC and higher than the background values (Fig. 2), which suggests that the emissions of these elements are mainly caused by human activities in cities. Overall, $\mathrm{Cd}, \mathrm{Cu}, \mathrm{Hg}, \mathrm{Pb}, \mathrm{Sb}$, and $\mathrm{Zn}$ demonstrated to be the typical urban contaminants and mostly influenced by the adjacent human activities with higher content to background ratios and SD values. $\mathrm{Ca}$ also had higher content to background ratios whereas smaller SD values, showing that it was mainly from urban anthropogenic emissions and relatively evenly distributed in the study areas.

For the sediment sample, the contents of $\mathrm{Ba}, \mathrm{Cd}, \mathrm{Ce}, \mathrm{Cu}, \mathrm{Hg}, \mathrm{La}, \mathrm{Ni}, \mathrm{Sr}, \mathrm{Ca}$, and $\mathrm{Na}$ were higher than the Beijing background values.

Fig. 2 Ratios between individual element contents and background values. 


\subsection{Spatial distribution of metals}

Eight metals ( $\mathrm{Ba}, \mathrm{Cd}, \mathrm{Cu}, \mathrm{Hg}, \mathrm{Pb}, \mathrm{Sb}, \mathrm{Zn}$, and $\mathrm{Ca})$, which exhibited much higher metal contents than the background values at certain sites, were selected to demonstrate their spatial distribution in the three sampling areas using the IDW in ArcGIS 10.0 (Fig. 3). The background levels of individual metals are all within the first content ranges in Fig. 3 with dark green color. The enrichment levels of all eight metals in BJC and MYT were higher than found in MYC, showing that there were intensive anthropogenic emissions from cities. Table 2 shows the important anthropogenic pollution sources for certain metal elements from previous studies. The $\mathrm{X}$ in the table represents the potential source is an important emission source for the corresponding metal element.

Fig. 3 showed the metal contents were quite different at different locations and varied very much for different metal elements, which exhibited quite diverse shapes and colors in Fig. 3. This is caused by the abundant impact from adjacent anthropogenic pollution emissions at various locations and different emission sources for different metal elements. Among the plotted eight metal elements, $\mathrm{Cu}$ and $\mathrm{Sb}$ demonstrated much higher contents in urban dust of BJC than those of MYT. Little enrichment of $\mathrm{Cu}$ and $\mathrm{Sb}$ was found in MYC. This showed that the emission sources of $\mathrm{Cu}$ and $\mathrm{Sb}$ mainly existed in cities. Among the 29 metal elements investigated, $\mathrm{Cu}$ and $\mathrm{Sb}$ were found to be the most distinct elements that were highly affected by the developing level and congestion status of the cities with much higher contents in dust in more developed and congested cities, e.g. BJC. The higher contents of $\mathrm{Cu}$ and $\mathrm{Sb}$ in $\mathrm{BJC}$ might be mainly due to the heavy traffic and increased brake usage in congested super city based on the fact that brake system was the main emission source of $\mathrm{Cu}$ and $\mathrm{Sb}$ shown in Table 2. In addition, higher $\mathrm{Cu}$ and $\mathrm{Sb}$ contents 
happened in southern and western part of BJC, where many long distance bus stations and railway stations located. This is another evidence that vehicle braking system emits much $\mathrm{Cu}$ and $\mathrm{Sb}$.

In MYT, the highest contents of nearly all the eight metals except Hg occurred around MYT5, the central area of MYT. As a small scale town with about 19,000 capita (http://www.my.bjstats.gov.cn/Page/181/InfoID/11739/SourceId/717/PubDate/2011-05-06/default. aspx), MYT5 was surrounded by the most important buildings of the town within $500 \mathrm{~m}$ radius range including Miyun county government center, Miyun county hospital, Miyun grand theater, Scitech outlet plaza (Miyun), Changan Shopping center. Therefore adjacent anthropogenic activity intensity largely determined the environmental metal contents and $\mathrm{Ba}, \mathrm{Cd}, \mathrm{Cu}, \mathrm{Pb}, \mathrm{Sb}, \mathrm{Zn}$, and $\mathrm{Ca}$ were found to be good indicators.

Table 2 Potential sources of metals from different industries and vehicles.

Fig. 3 Spatial distribution of selected metals in urban dust and rural surface soils.

\subsection{Pb isotope characteristics and $\mathbf{P b}$ potential sources}

To further understand the origin of $\mathrm{Pb}$ in the urban dust and surface soil, the $\mathrm{Pb}$ isotopic ratios (e.g., ${ }^{204} \mathrm{~Pb} /{ }^{206} \mathrm{~Pb},{ }^{207} \mathrm{~Pb} /{ }^{206} \mathrm{~Pb}$, and ${ }^{208} \mathrm{~Pb} /{ }^{206} \mathrm{~Pb}$ ) of three study areas and the major possible sources, such as vehicle exhaust, industries, and coal, were shown in Fig. 4. The Pb isotope ratios for Cenozoic basalts and Mesozoic-Cenozoic granites in Hebei Province were used as the background value (Zhang, 1989, Basu et al., 1991; Zhu, 1995). The Chinese coal line was the distribution of ${ }^{208} \mathrm{~Pb} /{ }^{206} \mathrm{~Pb}$ and ${ }^{207} \mathrm{~Pb} /{ }^{206} \mathrm{~Pb}$ of coal and coal combustion emissions from different areas and different thermal power stations in China (Mukai et al., 2001; Gao et al., 2004; Chen et al., 2005; Tan et al., 2006; $\mathrm{Hu}$ et al., 2013). It demonstrated the $\mathrm{Pb}$ isotope characters of major coals in China--ranges and relationship between ${ }^{208} \mathrm{~Pb} /{ }^{206} \mathrm{~Pb}$ and ${ }^{207} \mathrm{~Pb} /{ }^{206} \mathrm{~Pb}$. The Chinese coal line showed 
a similar $\mathrm{Pb}$ ratio to the Chinese $\mathrm{Pb}$ ore line, which was obtained from the data of Zheng et al. (2004) and Zhu et al. (2013). Results suggested that the coal and $\mathrm{Pb}$ ore have similar $\mathrm{Pb}$ isotope ratios, which were both underground resources. The Chinese coal and $\mathrm{Pb}$ ores were generally higher in ${ }^{208} \mathrm{~Pb} /{ }^{206} \mathrm{~Pb}$ ratio (Cumming and Richards, 1975; Hu et al., 2015a) than the $\mathrm{Pb}$ growth curve (Fig. 4). Fig. 4 showed that the $\mathrm{Pb}$ isotope ratio ${ }^{204} \mathrm{~Pb} /{ }^{206} \mathrm{~Pb}$ and ${ }^{207} \mathrm{~Pb} /{ }^{206} \mathrm{~Pb}$ increase in the following sequence: loess < vehicle exhaust $<$ industry $<$ aerosols. Coal combustion had a wider $\mathrm{Pb}$ ratio range, which covered the variability from vehicle exhaust and industrial processes.

For the samples collected in this study, the Pb isotope ratios of MYC soil covered the widest ratio ranges with ${ }^{204} \mathrm{~Pb} /{ }^{206} \mathrm{~Pb},{ }^{207} \mathrm{~Pb} /{ }^{206} \mathrm{~Pb}$, and ${ }^{208} \mathrm{~Pb} /{ }^{206} \mathrm{~Pb}$ of $0.0544-0.0635,0.8496-0.9560$, and 2.0790-2.3201, respectively, demonstrating a wide range of $\mathrm{Pb}$ sources in the MYC surface soil. Site MYC5, located in an iron mine, had the highest ${ }^{204} \mathrm{~Pb} /{ }^{206} \mathrm{~Pb},{ }^{207} \mathrm{~Pb} /{ }^{206} \mathrm{~Pb}$, and ${ }^{208} \mathrm{~Pb} /{ }^{206} \mathrm{~Pb}$ ratios in all samples, which indicated that the ore had higher ${ }^{204} \mathrm{~Pb} / 206 \mathrm{~Pb},{ }^{207} \mathrm{~Pb} / 206 \mathrm{~Pb}$, and ${ }^{208} \mathrm{~Pb} /{ }^{206} \mathrm{~Pb}$ ratios than other sources.

The $\mathrm{Pb}$ isotope ratios of urban dust in BJC and MYT, except BJC29 and MYT6, remained within a relatively narrow range, which indicated relatively consistent sources for urban dust. The three $\mathrm{Pb}$ isotope ratios for urban dust in BJC were distributed similarly to the MYT dust. The ${ }^{208} \mathrm{~Pb} /{ }^{206} \mathrm{~Pb}$ values of BJC and MYT all located below the Chinese coal line and Chinese $\mathrm{Pb}$ ore line, whereas the values of MYC were almost on these lines. Therefore $\mathrm{Pb}$ pollution in MYC was mainly related to the coal combustion. Most samples located higher than the $\mathrm{Pb}$ growth curve, except MYC33, showing that anthropogenic influences are present in the study area. The ratio of sediment sample was higher than most samples, indicating different $\mathrm{Pb}$ sources.

As shown in Fig. 4, the fine particle subsamples, BJC14b and BJC28b, had higher ${ }^{204} \mathrm{~Pb} /{ }^{206} \mathrm{~Pb}$, 
${ }^{207} \mathrm{~Pb} /{ }^{206} \mathrm{~Pb}$, and ${ }^{208} \mathrm{~Pb} /{ }^{206} \mathrm{~Pb}$ ratios than the coarse particle subsamples. The fine particle subsamples were located near the anthropogenic sources of coal combustion and vehicle exhaust, and the coarse particle subsamples were located near the background value. This indicated that fine particle subsamples might be more related to surrounding human activities than coarse subsamples.

The ${ }^{204} \mathrm{~Pb} /{ }^{206} \mathrm{~Pb}$ and ${ }^{208} \mathrm{~Pb} /{ }^{206} \mathrm{~Pb}$ ratios of the aerosols in Beijing (Liu et al., 2011) were generally higher than the urban dust samples (Fig. 4). Atmospheric deposition has an important influence on urban dust and rural surface soil, and the particles can transfer between aerosols and urban dust, rural surface soil (Bi et al., 2007). In this situation, atmospheric deposition can bring anthropogenic pollution from other areas for urban dust and rural surface soil. But the pollution from atmospheric deposition is the secondary pollution and is the combination of many end-members or different sources. Therefore, atmospheric deposition cannot be thought of as the original sources of urban dust and rural surface soil.

Fig. $4 \mathrm{~Pb}$ isotopic composition for urban dust and rural surface soil samples and some possible sources, ${ }^{204} \mathrm{~Pb} /{ }^{206} \mathrm{~Pb}$ vs ${ }^{207} \mathrm{~Pb} / 206 \mathrm{~Pb}$ and ${ }^{208} \mathrm{~Pb} /{ }^{206} \mathrm{~Pb}$ vs ${ }^{207} \mathrm{~Pb} / 206 \mathrm{~Pb}$.

\subsection{Source identification based on $\mathrm{Pb}$ isotope ratios}

The $\mathrm{Pb}$ isotope ratios from various sources were used to quantify the $\mathrm{Pb}$ pollution contribution proportion from different sources. As shown in the previous discussion, coal combustion, vehicle exhaust, and industrial activities had a major influence on $\mathrm{Pb}$ pollution in the study area. Therefore, four end-members (e.g., background, coal combustion, vehicle exhaust, and industry) were assumed to contribute $100 \%$ to the $\mathrm{Pb}$ in the samples. If the proportions of each of the end-members $k$ were known, the $\mathrm{Pb}$ isotope ratios can be calculated as follows: 


$$
\begin{aligned}
& (207 / 206)_{\mathrm{c}, \mathrm{i}}=\sum_{\mathrm{j}=1}^{4} \mathrm{k}_{\mathrm{j}, \mathrm{i}}(207 / 206)_{\mathrm{j}} \\
& (204 / 206)_{\mathrm{c}, \mathrm{i}}=\sum_{\mathrm{j}=1}^{4} \mathrm{k}_{\mathrm{j}, \mathrm{i}}(204 / 206)_{\mathrm{j}} \\
& (208 / 206)_{\mathrm{c}, \mathrm{i}}=\sum_{\mathrm{j}=1}^{4} \mathrm{k}_{\mathrm{j}, \mathrm{i}}(208 / 206)_{\mathrm{j}} \\
& \sum_{j=1}^{4} k_{j, i}=1, \text { where } 0 \leq k_{j, i} \leq 1
\end{aligned}
$$

where $(207 / 206)_{c, i},(204 / 206)_{c, i}$, and $(208 / 206)_{c, i}$ represent the calculated ${ }^{207} \mathrm{~Pb} /{ }^{206} \mathrm{~Pb}$, ${ }^{204} \mathrm{~Pb} /{ }^{206} \mathrm{~Pb}$, and ${ }^{208} \mathrm{~Pb} /{ }^{206} \mathrm{~Pb}$ ratios for sample $I$, respectively; $(207 / 206)_{j},(204 / 206)_{j}$, and $(208 / 206)_{j}$ give the ${ }^{207} \mathrm{~Pb} /{ }^{206} \mathrm{~Pb},{ }^{204} \mathrm{~Pb} /{ }^{206} \mathrm{~Pb}$, and ${ }^{208} \mathrm{~Pb} /{ }^{206} \mathrm{~Pb}$ ratios for end-member $j$, respectively; $j$ represents the end-members with $j=1$ for background, $j=2$ for coal combustion, $j$ $=3$ for vehicle exhaust, and $j=4$ for industry; and $k_{j, i}$ is the mass proportion of end-member $j$ for sample $i$. The $\mathrm{Pb}$ isotope ratios for the end-members were achieved from related studies and the mean values of different studies were calculated as shown in Table 3. Only the $\mathrm{Pb}$ isotope ratios of the end-members background, coal combustion, and industrial activities from Beijing area were used to calculate the pollution source proportion. For vehicle exhaust, the data from other cities were also used due to the unified standard for gasoline and diesel in the whole China.

Table 3 The Pb isotope ratios of four end-members (background, coal combustion, vehicle exhaust, industry)

To obtain $\mathrm{Pb}$ isotope ratio proportions for different end-members, a least-square optimization method was used to minimize the sum of squared differences between the calculated and observed isotope ratios with the objective function as follows:

$\mathrm{F}\left(k_{j, i}\right)=\min \sum\left(\left((207 / 206)_{\mathrm{c}, \mathrm{i}}-(207 / 206)_{\mathrm{i}}\right)^{2}+\left((204 / 206)_{\mathrm{c}, \mathrm{i}}-(204 / 206)_{\mathrm{i}}\right)^{2}+((208 /\right.$

$\left.\left.206)_{c, i}-(208 / 206)_{i}\right)^{2}\right)$

where $(207 / 206)_{c, i},(204 / 206)_{c, i}$, and $(208 / 206)_{c, i}$ are described as Equations (1)-(4) and $(207 / 206)_{i},(204 / 206)_{i}$, and $(208 / 206)_{i}$ are the observed isotope ratios for sample $i$.

Lsqlin in Matlab R2010b was used to obtain the optimized solution. The mass proportions of 
different end-members for each sample $k_{j, i}$ were calculated and results were shown in Fig. 5. Coal and vehicle exhaust were the most important $\mathrm{Pb}$ pollution sources and the average of the sum of their mean mass fraction was $74.6 \%$ of the total $\mathrm{Pb}$ pollution. The calculated mass proportions of different pollution sources had a large variance for MYC samples but a much smaller variance for BJC and MYT samples, indicating relatively similar $\mathrm{Pb}$ pollution compositions for different locations in the urban area. The $\mathrm{Pb}$ pollution proportion from industry was the lowest in the urban area with mean fractions of $9.7 \%$ and $11.5 \%$ for BJC and MYT, respectively. Coal combustion had the highest $\mathrm{Pb}$ pollution fraction with mean values of $41.5 \%, 38.6 \%$, and $39.8 \%$ for BJC, MYT, and MYC, respectively. This result indicated that $\mathrm{Pb}$ pollution from coal combustion was the major source of $\mathrm{Pb}$ pollution in study area. This was coincident with coal was still the major energy source for China (Xie et al., 2015). The large variance of calculated $\mathrm{Pb}$ mass proportions for MYC indicated a much more uncertainty of $\mathrm{Pb}$ sources apportionment for MYC soil than for the urban dust. Previous studies also showed a variety of anthropogenic $\mathrm{Pb}$ input into surface soils including traffic activities, industries, and so on (Facchinelli et al., 2001; Wong et al.,2002; Micó et al., 2006).

Vehicle exhaust was the second most important $\mathrm{Pb}$ pollution source with mean fractions of 35.3\%, 33.6\%, and 33.0\% for BJC, MYT, and MYC, respectively. Although leaded gasoline was banned in 1997 in Beijing (Hu et al., 2015b), the results demonstrated major Pb pollution from vehicle exhaust, which may be from diesel and low-quality unleaded gasoline fuels.

For subsamples $\mathrm{BJC} 14 \mathrm{~b}$ and $\mathrm{BJC} 28 \mathrm{~b}$, the $\mathrm{Pb}$ pollution from coal and vehicle exhaust was stronger than from the corresponding coarse particles. The mass fractions from the background in $\mathrm{BJC} 14 \mathrm{a}$ and $\mathrm{BJC} 28 \mathrm{a}$ were higher than those in $\mathrm{BJC} 14 \mathrm{~b}$ and $\mathrm{BJC} 28 \mathrm{~b}$. This confirms that there was 
more anthropogenic $\mathrm{Pb}$ pollution in the fine particles than in the corresponding coarse particles (Lau and Stenstrom, 2005).

The $\mathrm{Pb}$ pollution mass fractions for the sediment samples were $52.5 \%$ from background, $0.0185 \%$ from coal, $6.2 \%$ from vehicle exhaust, and $41.5 \%$ from industry. This result suggests that the $\mathrm{Pb}$ pollution in sediment was mainly from the background soil and upstream industry discharges. More attention should be paid to the industrial wastewater discharge into the river for better pollution control.

Fig. 5 Mass proportion of different pollution sources in BJC, MYT, and MYC through the Pb isotope ratio calculations.

\section{Conclusions}

The influence of human activities on metal contents in urban surface dust and rural surface soils was well demonstrated by the large metal content to background values. Among the 29 metals studied, the ratio of observed to background was higher than 2 for $\mathrm{Cd}, \mathrm{Cu}, \mathrm{Hg}, \mathrm{Pb}, \mathrm{Sb}, \mathrm{Zn}$, and $\mathrm{Ca}$. The contents of $\mathrm{Ba}, \mathrm{Cd}, \mathrm{Cr}, \mathrm{Cu}, \mathrm{Hg}, \mathrm{Pb}, \mathrm{Sb}, \mathrm{Sr}, \mathrm{Zn}, \mathrm{Ca}$ and $\mathrm{Mg}$ from the urban areas of BJC and MYT were higher than those from rural MYC, suggesting that the elevated contents were mainly caused by the increased human activities in the urban areas. Spatial distribution showed that $\mathrm{Cu}$ and $\mathrm{Sb}$ contents were the most distinctive metal elements mainly influenced by different development and congestion levels.

The $\mathrm{Pb}$ isotope ratios (e.g., ${ }^{204} \mathrm{~Pb} / 206 \mathrm{~Pb},{ }^{207} \mathrm{~Pb} /{ }^{206} \mathrm{~Pb}$, and ${ }^{208} \mathrm{~Pb} / 206 \mathrm{~Pb}$ ) were used to understand the origin of $\mathrm{Pb}$ sources in further detail. The $\mathrm{Pb}$ isotope ratios of urban dust from BJC and MYT had a narrower range than MYC, and located near the $\mathrm{Pb}$ isotope ratios of anthropogenic inputs. Most of the samples had a lower ${ }^{208} \mathrm{~Pb} /{ }^{206} \mathrm{~Pb}$ ratio than the Chinese coal line and Chinese $\mathrm{Pb}$ ore 
line. Quantitative calculation results for the end-members proportion showed that coal combustion had the highest mass fraction for $\mathrm{Pb}$ pollution and vehicle exhaust was the second largest pollution source. In addition, urban dust with the particles smaller than $120 \mu \mathrm{m}$ got more anthropogenic $\mathrm{Pb}$ influence than coarse particles.

For river sediment, the $\mathrm{Pb}$ isotope results showed that the $\mathrm{Pb}$ pollution in river sediment was mainly caused by the background and up-stream industrial sources.

\section{Acknowledgment}

This research was supported by the Fund for Innovative Research Group of the National Natural Science Foundation of China (Grant No. 51421065), National Science Foundation of China (Grant 51278054), the State Key Program of National Natural Science of China (Grant 41530635), and the Fundamental Research Funds for the Central Universities. The authors are grateful for the support.

\section{References}

Acosta, J.A., Gabarrón, M., Faz, A., Martínez-Martínez, S., Zornoza, R., Arocena, J.M., 2015. Influence of population density on the concentration and speciation of metals in the soil and street dust from urban areas. Chemosphere 134, 328-337.

Adachi, K., Tainosho, Y., 2004. Characterization of heavy metal particles embedded in tire dust. Environment International 30, 1009-1017.

Ault, W.U., Senechal, R.G., Erlebach, W.E., 1970. Isotopic composition as a natural tracer of lead in the environment. Environmental Science \& Technology 4, 305-313.

Basu, A.R., Junwen, W., Wankang, H., Guanghong, X., Tatsumoto, M., 1991. Major element, REE, and Pb, Nd and $\mathrm{Sr}$ isotopic geochemistry of Cenozoic volcanic rocks of eastern China: implications for their origin from suboceanic-type mantle reservoirs. Earth and Planetary Science Letters 105, 149-169.

Beijing Statistics Bureau, 2013. Beijing statistical yearbook. China Statistics Press, Beijing. (in Chinese)

Bi, X., Feng, Y., Wu, J., Wang, Y., Zhu, T., 2007. Source apportionment of $\mathrm{PM}_{10}$ in six cities of northern China. Atmospheric Environment 41, 903-912.

Bi, X., Liang, S., Li, X., 2013. A novel in situ method for sampling urban soil dust: Particle size distribution, trace metal concentrations, and stable lead isotopes. Environmental Pollution 177, 48-57. 
Charlesworth, S., Miguel, E., Ordóñez, A., 2011. A review of the distribution of particulate trace elements in urban terrestrial environments and its application to considerations of risk. Environmental Geochemistry and Health 33, 103-123.

Chen, J., Tan, M., Li, Y., Zhang, Y., Lu, W., Tong, Y., Zhang, G., Li, Y., 2005. A lead isotope record of Shanghai atmospheric lead emissions in total suspended particles during the period of phasing out of leaded gasoline. Atmospheric Environment 39, 1245-1253.

Cheng, H., Hu, Y., 2010. Lead (Pb) isotopic fingerprinting and its applications in lead pollution studies in China: A review. Environmental Pollution 158, 1134-1146.

China National Environmental Monitoring Center, 1990. The Background Concentrations of Soil Elements of China. China Environmental Science Press, Beijing. (in Chinese)

Christoforidis, A., Stamatis, N., 2009. Heavy metal contamination in street dust and roadside soil along the major national road in Kavala's region, Greece. Geoderma 151, 257-263.

Cumming, G.L., Richards, J.R., 1975. Ore lead isotope ratios in a continuously changing earth. Earth and Planetary Science Letters 28, 155-171.

Davis, A.P., Shokouhian, M., Ni, S., 2001. Loading estimates of lead, copper, cadmium, and zinc in urban runoff from specific sources. Chemosphere 44, 997-1009.

Díaz-Somoano, M., Kylander, M.E., López-Antón, M.A., Suárez-Ruiz, I., Martínez-Tarazona, M.R., Ferrat, M., Kober, B., Weiss, D.J., 2009. Stable lead isotope compositions in selected coals from around the world and implications for present day aerosol source tracing. Environmental Science \& Technology 43, 1078-1085.

Egodawatta, P., Ziyath, A.M., Goonetilleke, A., 2013. Characterising metal build-up on urban road surfaces. Environmental Pollution 176, 87-91.

Facchinelli, A., Sacchi, E., Mallen, L., 2001. Multivariate statistical and GIS-based approach to identify heavy metal sources in soils. Environmental Pollution 114, 313-324.

Faure G., 1986. Principles of isotope geology. John Wiley and Sons, New York.

Franco-Uría, A., López-Mateo, C., Roca, E., Fernández-Marcos, M.L., 2009. Source identification of heavy metals in pastureland by multivariate analysis in NW Spain. Journal of Hazardous Materials 165, 1008-1015.

Gao, Z., Yin, G., Ni, S., Zhang, C., 2004. Geochemical features of the urban environmental lead isotope in Chengdu city. Carsologica Sinica 23, 267-272. (in Chinese)

Gao, B., Zhou, H., Liang, X., Tu, X., 2013. Cd isotopes as a potential source tracer of metal pollution in river sediments. Environmental Pollution 181, 340-343.

GB, 1995. Soil environmental quality standard (GB15618-1995). (in Chinese)

Granero, S., Domingo, J.L., 2002. Levels of metals in soils of Alcalá de Henares, Spain: Human health risks. Environment International 28, 159-164.

Gu, Y., Wang, Z., Lu, S., Jiang, S., Mu, D., Shu, Y., 2012. Multivariate statistical and GIS-based approach to identify source of anthropogenic impacts on metallic elements in sediments from the mid Guangdong coasts, China. Environmental Pollution 163, 248-255.

Han, L., Gao, B., Wei, X., Gao, L., Xu, D., Sun, K., 2015. The characteristic of Pb isotopic compositions in different chemical fractions in sediments from Three Gorges Reservoir, China. Environmental Pollution 206, 627-635.

http://www.my.bjstats.gov.cn/Page/181/InfoID/11739/SourceId/717/PubDate/2011-05-06/default.aspx (in chinese)

$\mathrm{Hu}, \mathrm{G}$., Yu, R., Zheng, Z., 2013. Application of stable lead isotopes in tracing heavy-metal pollution sources in the sediments. Acta Scientiae Circumstantiae33, 1326-1331. (in Chinese)

Hu, X., Sun, Y., Ding, Z., Zhang, Y., Wu, J., Lian, H., Wang, T., 2014. Lead contamination and transfer in urban environmental compartments analyzed by lead levels and isotopic compositions. Environmental Pollution 187, 
42-48.

Hu, N., Huang, P., Liu, J., Shi, X., Ma, D., Zhu, A., Zhang, J., Zhang, H., He, L., 2015a. Tracking lead origin in the Yellow River Estuary and nearby Bohai Sea based on its isotopic composition. Estuarine, Coastal and Shelf Science 163, 99-107.

Hu, N., Huang, P., Zhang, H., Zhu, A., He, L., Zhang, J., Liu, J., Shi, X., Ma, D., 2015b. Tracing the Pb origin using stable $\mathrm{Pb}$ isotope ratios in sediments of Liaodong Bay, China. Continental Shelf Research 111, 268-278.

Ip, C.C.M., Li, X.D., Zhang, G., Wong, C.S.C., Zhang, W.L., 2005. Heavy metal and Pb isotopic compositions of aquatic organisms in the Pearl River Estuary, South China. Environmental Pollution 138, 494-504.

Lau, S., Stenstrom, M.K., 2005. Metals and PAHs adsorbed to street particles. Water Research 39, 4083-4092.

Lau, S., Han, Y., Kang, J., Kayhanian, M., Stenstrom, M.K., 2009. Characteristics of highway stormwater runoff in Los Angeles: metals and polycyclic aromatic hydrocarbons. Water Environment Research 81, 308-318.

Li, X., Poon, C., Liu, P.S., 2001. Heavy metal contamination of urban soils and street dusts in Hong Kong. Applied Geochemistry 16, 1361-1368.

Li, Y., Xiang, L., Tian, P., Liu, J., 2013. Desorption characteristics of total phosphorus and heavy metals from impervious urban surface sediments. Chinese Science Bulletin 58, 3357-3360.

Li, Y., Yu, Y., Yang, Z., Shen, Z., Wang, X., Cai, Y., 2016. A comparison of metal distribution in surface dust and soil among super city, town, and rural area. Environmental Science and Pollution Research 23, 7849-7860.

Liu, X., Zhu, X., Dong, S., Li, Y., Widory, D., Yang, H., Li, B., 2011. Lead isotopic measurements and source study for size-selective aerosol samples in Beijing. Journal of Chinese Mass Spectrometry Society 32. (in chinese)

Liu, E., Yan, T., Birch, G., Zhu, Y., 2014. Pollution and health risk of potentially toxic metals in urban road dust in Nanjing, a mega-city of China. Science of the Total Environment 476-477, 522-531.

Lu, X., Wang, L., Li, L.Y., Lei, K., Huang, L., Kang, D., 2010. Multivariate statistical analysis of heavy metals in street dust of Baoji, NW China. Journal of Hazardous Materials 173, 744-749.

Lu, X., Zhang, X., Li, L.Y., Chen, H., 2014. Assessment of metals pollution and health risk in dust from nursery schools in Xi'an, China. Environmental Research 128, 27-34.

Madarang, K.J., Kang, J., 2014. Evaluation of accuracy of linear regression models in predicting urban stormwater discharge characteristics. Journal of Environmental Sciences 26, 1313-1320.

Micó, C., Recatalá, L., Peris, M., Sánchez, J., 2006. Assessing heavy metal sources in agricultural soils of an European Mediterranean area by multivariate analysis. Chemosphere 65, 863-872.

Mukai, H., Tanaka, A., Fujii, T., Zeng, Y., Hong, Y., Tang, J., Guo, S., Xue, H., Sun, Z., Zhou, J., Xue, D., Zhao, J., Zhai, G., Gu, J., Zhai, P., 2001. Regional characteristics of sulfur and lead isotope ratios in the atmosphere at several chinese urban sites. Environmental Science \& Technology 35, 1064-1071.

Sezgin, N., Ozcan, H.K., Demir, G., Nemlioglu, S., Bayat, C., 2004. Determination of heavy metal concentrations in street dusts in Istanbul E-5 highway. Environment International 29, 979-985.

Song, N., Ma, J., Yu, Y., Yang, Z., Li, Y., 2015. New observations on PAH pollution in old heavy industry cities in northeastern China. Environmental Pollution 205, 415-423.

Stigliani, W.M., Doelman, P., Salomons, W., Schulin, R., Smidt, G.R., Van der Zee, S.E.A.T., 1991. Chemical time bombs: predicting the unpredictable. Environment: Science and Policy for Sustainable Development 33, 4-30.

Tan, M.G., Zhang, G.L., Li, X.L., Zhang, Y.X., Yue, W.S., Chen, J.M., Wang, Y.S., Li, A.G., Li, Y., Zhang, Y.M., Shan, Z.C., 2006. Comprehensive study of lead pollution in shanghai by multiple techniques. Analytical Chemistry 78, 8044-8050.

Widory, D., Liu, X., Dong, S., 2010. Isotopes as tracers of sources of lead and strontium in aerosols (TSP \& PM2.5) in Beijing. Atmospheric Environment 44, 3679-3687. 
Wong, S.C., Li, X.D., Zhang, G., Qi, S.H., Min, Y.S., 2002. Heavy metals in agricultural soils of the Pearl River Delta, South China. Environmental Pollution 119, 33-44.

Xie, W., Sheng, P., Guo, X., 2015. Coal, oil, or clean energy: Which contributes most to the low energy efficiency in China? Utilities Policy 35, 67-71

Zhang, L., 1989. Petrogenetic and minerogenetic theories and prospecting. Press of Beijing Technological University, Beijing 267. (in Chinese)

Zhao, H., Li, X., 2013. Risk assessment of metals in road-deposited sediment along an urban-rural gradient. Environmental Pollution 174, 297-304.

Zheng, J., Tan, M., Shibata, Y., Tanaka, A., Li, Y., Zhang, G., Zhang, Y., Shan, Z., 2004. Characteristics of lead isotope ratios and elemental concentrations in $\mathrm{PM}_{10}$ fraction of airborne particulate matter in Shanghai after the phase-out of leaded gasoline. Atmospheric Environment 38, 1191-1200.

Zhu, B., 1995. The mapping of geochemical provinces in China based on Pb isotopes. Journal of Geochemical Exploration 55, 171-181.

Zhu, B., Chen, Y., Peng, J., 2001. Lead isotope geochemistry of the urban environment in the Pearl River Delta. Applied Geochemistry 16, 409-417.

Zhu, B., Chen, Y., Chang, X., 2003. Application of Pb isotopic mapping to environment evaluation in China. Chemical Speciation and Bioavailability 14, 49-56.

Zhu, Z., Sun, G., Bi, X., Li, Z., Yu, G., 2013. Identification of trace metal pollution in urban dust from kindergartens using magnetic, geochemical and lead isotopic analyses. Atmospheric Environment 77, 9-15.

Žibret, G., 2012. Impact of dust filter installation in ironworks and construction on brownfield area on the toxic metal concentration in street and house dust (Celje, Slovenia). Ambio 41, 292-301. 


\section{List of figures:}

Fig. 1 Sampling locations in Beijing center (BJC), Miyun Town (MYT), and Miyun County (MYC), China.

Fig. 2 Ratios between individual element contents and background values.

Fig. 3 Spatial distribution of selected metals in urban dust and rural surface soils.

Fig. $4 \mathrm{~Pb}$ isotopic composition for urban dust and rural surface soil samples and some possible sources, ${ }^{204} \mathrm{~Pb} /{ }^{206} \mathrm{~Pb}$ vs ${ }^{207} \mathrm{~Pb} /{ }^{206} \mathrm{~Pb}$ and ${ }^{208} \mathrm{~Pb} /{ }^{206} \mathrm{~Pb}$ vs ${ }^{207} \mathrm{~Pb} /{ }^{206} \mathrm{~Pb}$.

Fig. 5 Mass proportion of different pollution sources in BJC, MYT, and MYC through the $\mathrm{Pb}$ isotope ratio calculations. 


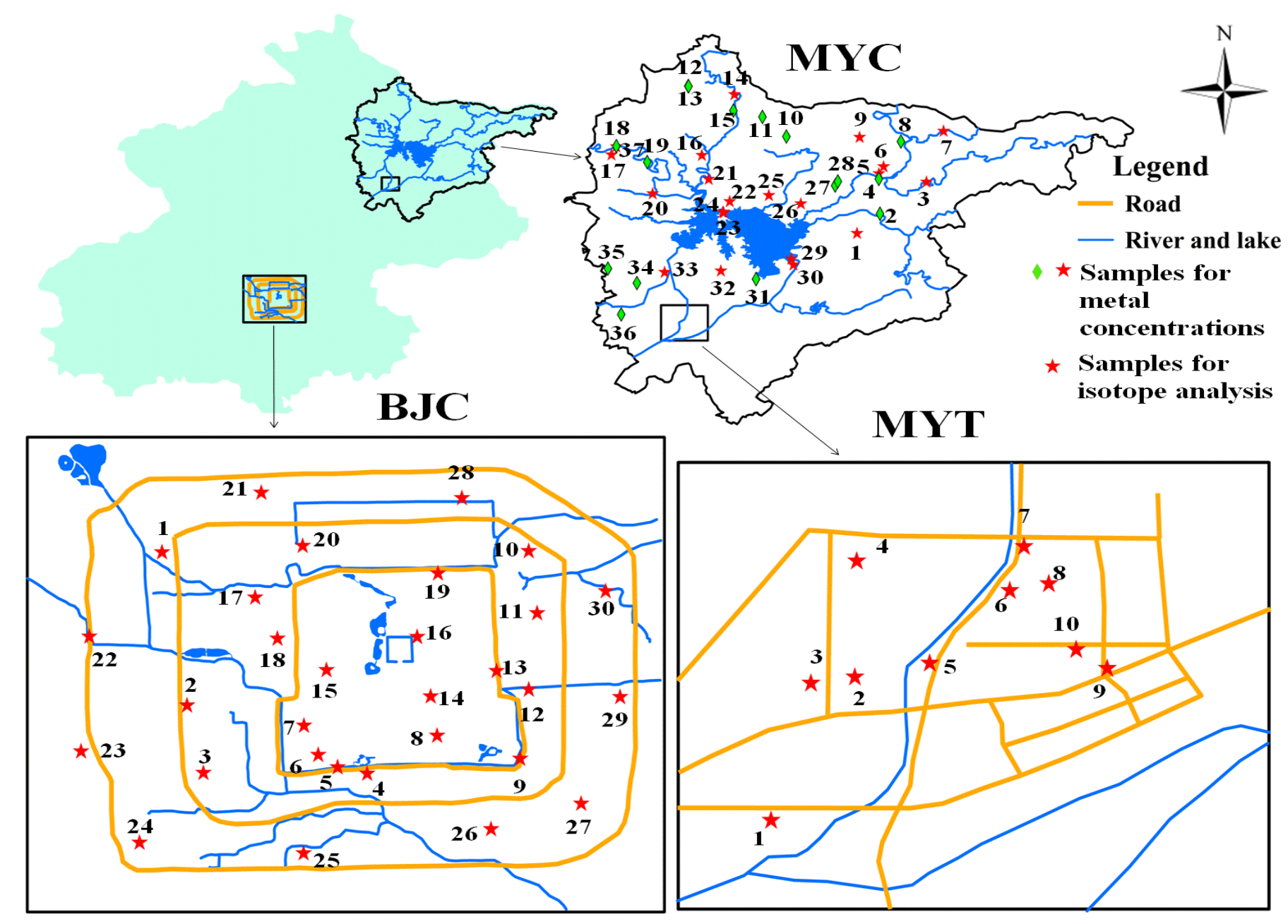

Fig. 6 Sampling locations in Beijing center (BJC), Miyun Town (MYT), and Miyun County (MYC), China. 


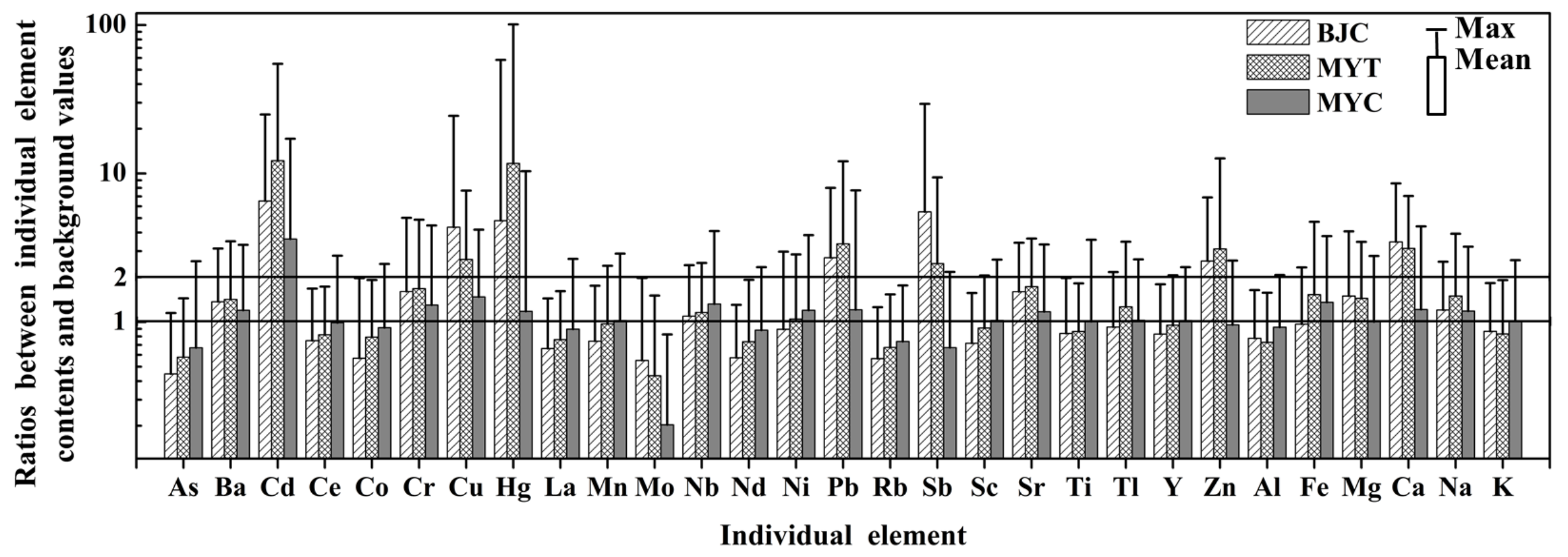

Fig. 7 Ratios between individual element contents and background values. 


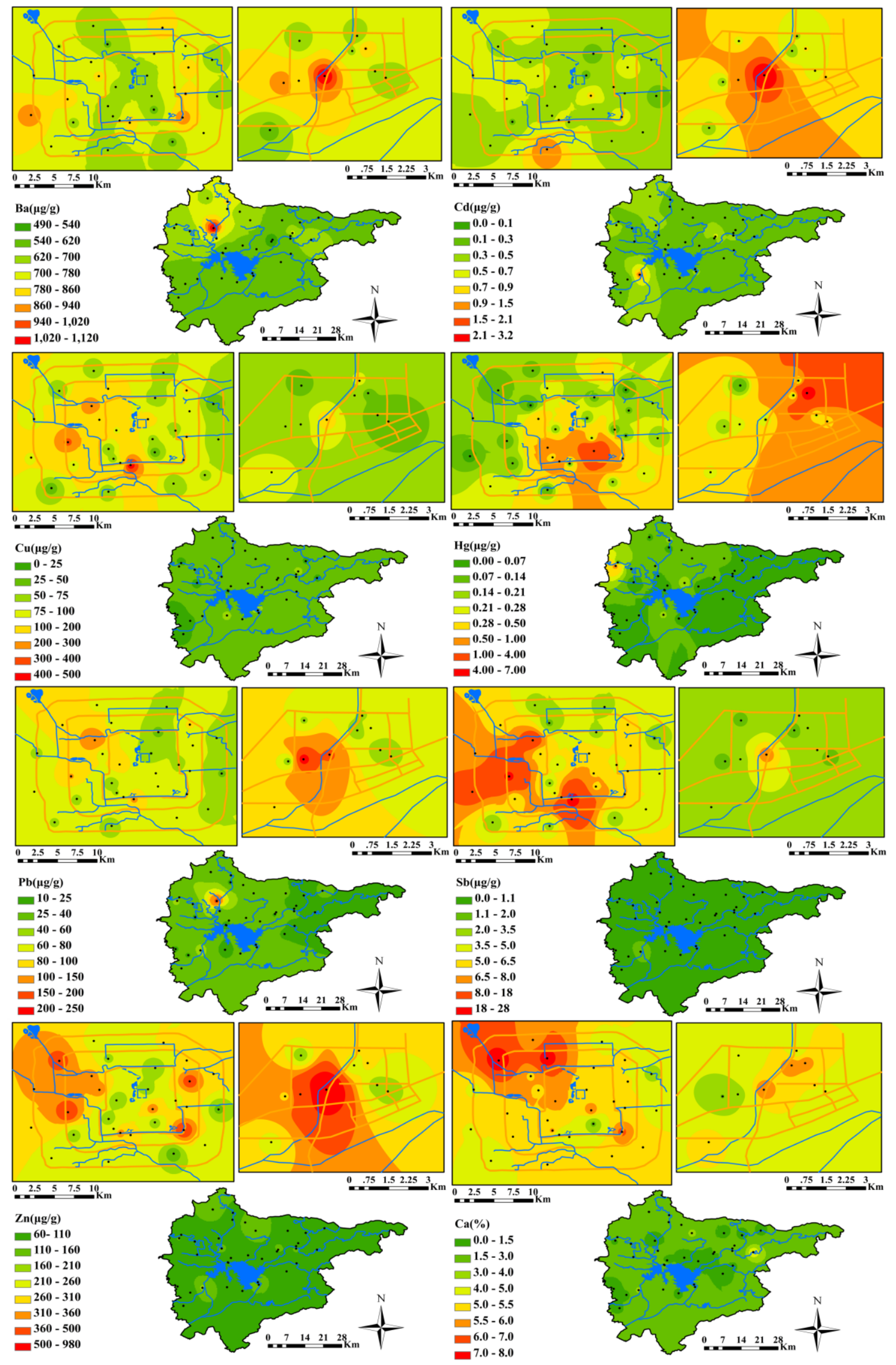

Fig. 8 Spatial distribution of selected metals in urban dust and rural surface soils. 


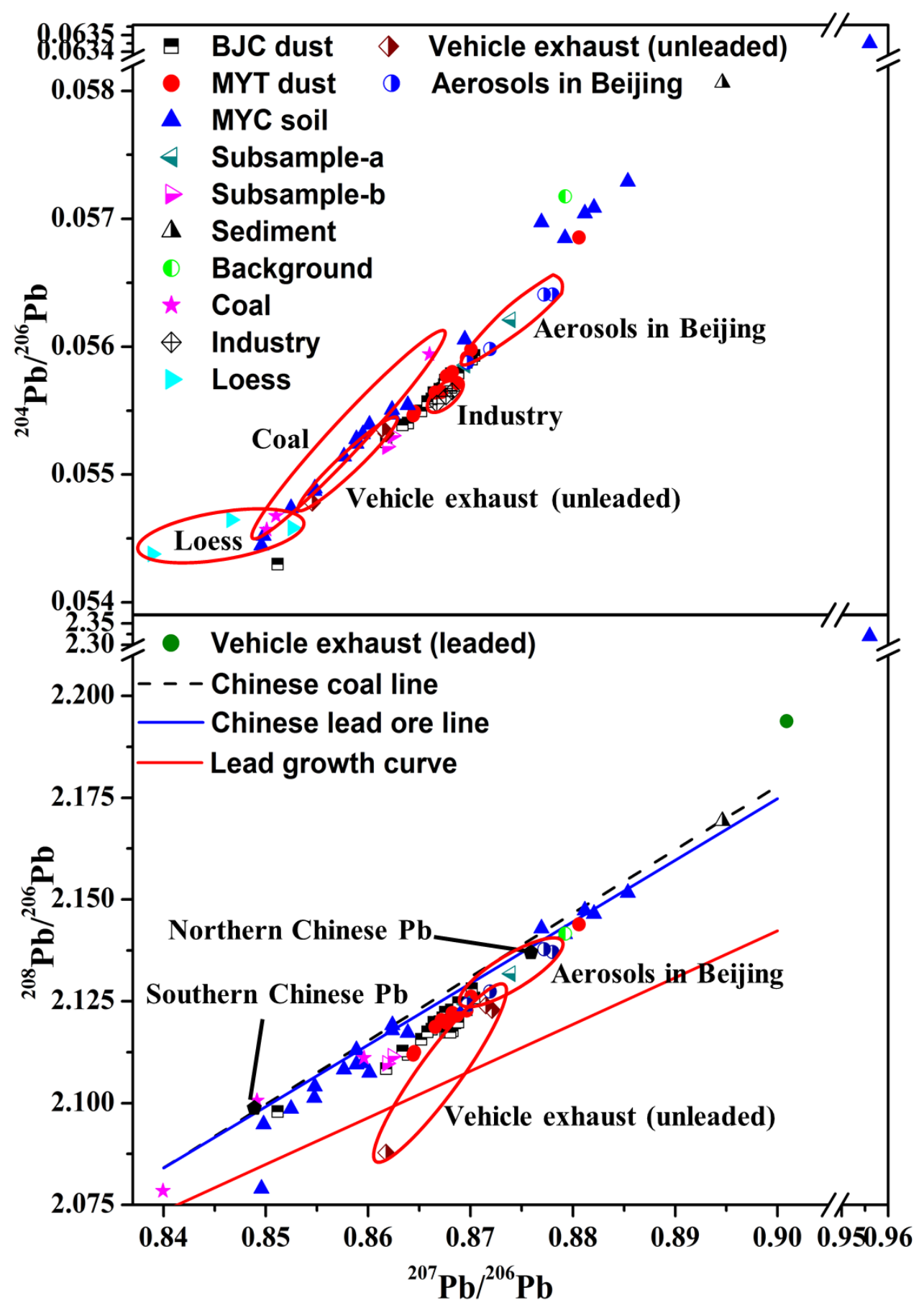

Fig. $9 \mathrm{~Pb}$ isotopic composition for urban dust and rural surface soil samples and some possible sources, ${ }^{204} \mathrm{~Pb} /{ }^{206} \mathrm{~Pb}$ vs ${ }^{207} \mathrm{~Pb} /{ }^{206} \mathrm{~Pb}$ and ${ }^{208} \mathrm{~Pb} /{ }^{206} \mathrm{~Pb}$ vs ${ }^{207} \mathrm{~Pb} /{ }^{206} \mathrm{~Pb}$.

Data sources:

Background - from Zhang (1989), Basu et al. (1991) and Zhu (1995).

Aerosols in Beijing- mainly from Liu et al. (2011).

Coal - including coal combustion, from Mukai et al. (2001); Gao et al. (2004); Tan et al. (2006); Widory et al. (2010).

Industry - mainly from lead refining plants near Beijing, Widory et al. (2010).

Vehicle exhaust - including gasoline and diesel, Zhu et al. (2001), Gao et al. (2004), Chen et al. (2005), Tan et al. (2006). 
Loess - obtained from Widory et al. (2010).

Chinese coal line - drawn based on data from Mukai et al. (2001); Gao et al. (2004); Chen et al. (2005); Tan et al. (2006); Hu et al. (2013).

Chinese lead ore line - obtained from the linear regression of data from Zheng et al. (2004), Zhu et al. (2013).

Lead growth curve - from Cumming and Richards (1975); Hu et al. (2015a). 


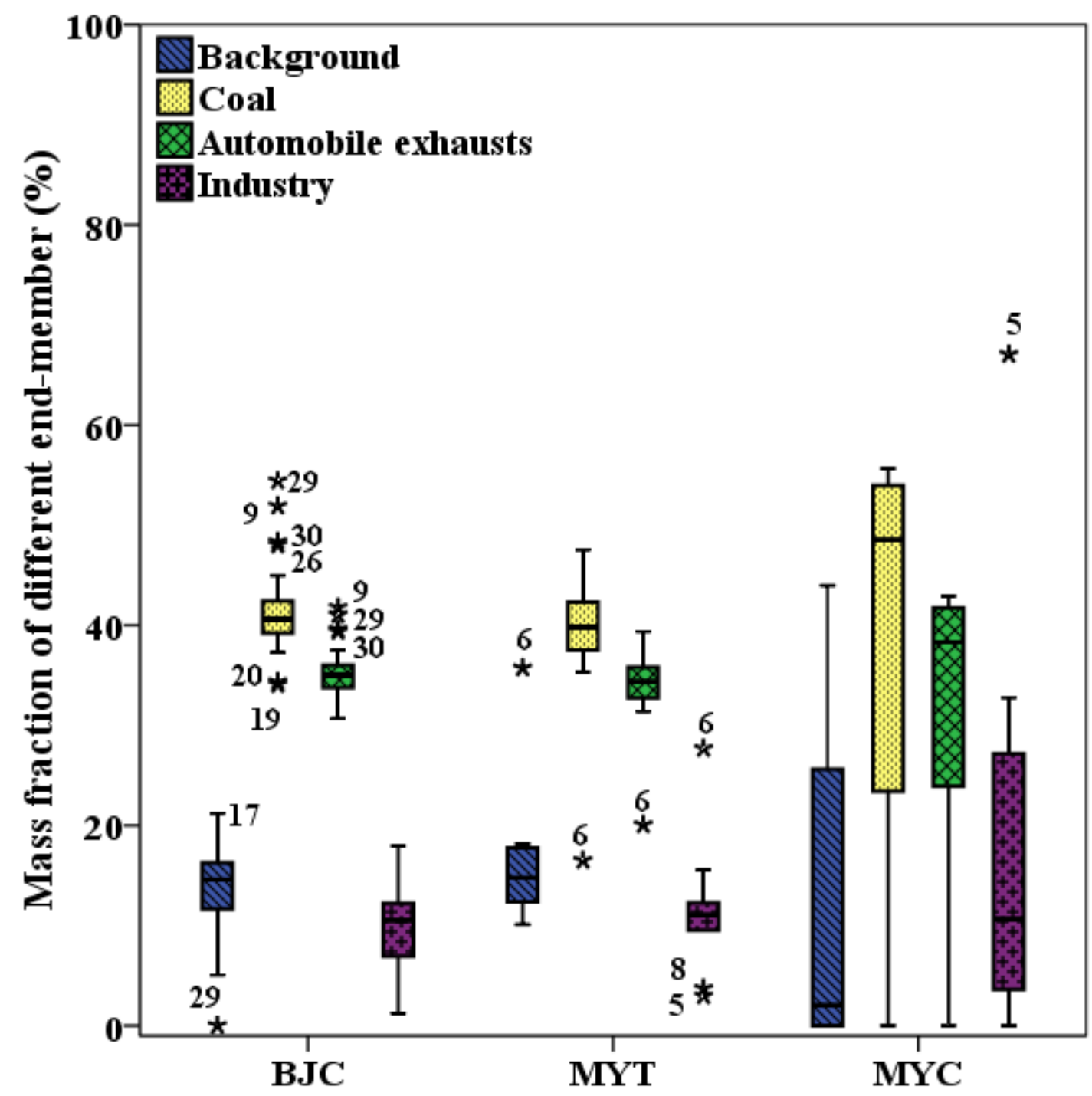

Fig. 10 Mass proportion of different pollution sources in BJC, MYT, and MYC through the $\mathrm{Pb}$ isotope ratio calculations. 


\section{List of Tables:}

Table1 Descriptive statistics of metal contents in urban dust and rural surface soil samples

Table 2 Potential sources of metals from different industries and vehicles

Table 3 Lead isotope ratios of four end-members 
Table 4 Descriptive statistics of metal contents in urban dust and rural surface soil samples

\begin{tabular}{|c|c|c|c|c|c|c|c|c|c|c|c|c|c|c|c|c|}
\hline & \multirow{2}{*}{$\begin{array}{c}\text { Background } \\
\text { value* }\end{array}$} & \multicolumn{4}{|c|}{$\operatorname{BJC}(\mathrm{n}=30)$} & \multicolumn{4}{|c|}{$\operatorname{MYT}(\mathrm{n}=10)$} & \multicolumn{4}{|c|}{ MYC(n=36) } & \multirow{2}{*}{$\begin{array}{l}\text { Sediment } \\
\qquad(\mathrm{n}=1)\end{array}$} & \multicolumn{2}{|c|}{ Recovery rate $* *$} \\
\hline & & mean & $\min$ & $\max$ & SD & mean & $\min$ & $\max$ & SD & mean & $\min$ & $\max$ & SD & & $\min$ & $\max$ \\
\hline $\operatorname{As}(\mu \mathrm{g} / \mathrm{g})$ & 9.7 & 4.34 & 2.85 & 6.83 & 0.77 & 5.62 & 3.32 & 8.37 & 1.51 & 6.61 & 1.81 & 18.38 & 3.03 & 3.10 & 0.867 & 1.12 \\
\hline $\mathrm{Ba}(\mu \mathrm{g} / \mathrm{g})$ & 531 & 728 & 596 & 932 & 95 & 754 & 595 & 1100 & 163 & 631 & 500 & 1119 & 109 & 886 & 0.958 & 1.05 \\
\hline $\mathrm{Cd}(\mu \mathrm{g} / \mathrm{g})$ & 0.074 & 0.48 & 0.18 & 1.37 & 0.22 & 0.90 & 0.34 & 3.16 & 0.85 & 0.27 & 0.08 & 1.00 & 0.19 & 0.22 & 0.832 & 1.22 \\
\hline $\mathrm{Ce}(\mu \mathrm{g} / \mathrm{g})$ & 77.3 & 57.9 & 45.5 & 71.6 & 6.4 & 63.4 & 54.6 & 70.4 & 4.7 & 76.3 & 48.6 & 139.6 & 17.1 & 83.4 & 0.971 & 1.14 \\
\hline $\operatorname{Co}(\mu \mathrm{g} / \mathrm{g})$ & 15.6 & 8.9 & 6.0 & 21.9 & 2.6 & 12.3 & 9.6 & 17.6 & 2.4 & 14.4 & 8.1 & 24.1 & 4.2 & 10.2 & 0.923 & 1.07 \\
\hline $\operatorname{Cr}(\mu \mathrm{g} / \mathrm{g})$ & 68.1 & 109.3 & 49.6 & 233.0 & 38.2 & 114.3 & 65.0 & 217.8 & 41.9 & 89.4 & 48.0 & 215.5 & 38.9 & 59.6 & 0.827 & 1.16 \\
\hline $\mathrm{Cu}(\mu \mathrm{g} / \mathrm{g})$ & 23.6 & 102.5 & 29.0 & 475.1 & 94.0 & 62.3 & 36.3 & 118.3 & 26.8 & 34.9 & 18.1 & 64.0 & 12.0 & 31.5 & 0.925 & 1.04 \\
\hline $\operatorname{Hg}(\mu \mathrm{g} / \mathrm{g})$ & 0.069 & 0.33 & 0.04 & 3.69 & 0.67 & 0.81 & 0.07 & 6.16 & 1.88 & 0.08 & 0.02 & 0.63 & 0.10 & 0.08 & 0.823 & 1.10 \\
\hline $\mathrm{La}(\mu \mathrm{g} / \mathrm{g})$ & 42.7 & 28.3 & 21.6 & 33.2 & 3.0 & 32.5 & 27.4 & 36.2 & 2.7 & 38.0 & 24.2 & 75.3 & 9.3 & 45.8 & 0.914 & 1.09 \\
\hline $\operatorname{Mn}(\mu \mathrm{g} / \mathrm{g})$ & 705 & 524 & 393 & 713 & 62 & 685 & 513 & 1000 & 162 & 725 & 337 & 1314 & 174 & 610 & 0.951 & 1.06 \\
\hline $\operatorname{Mo}(\mu \mathrm{g} / \mathrm{g})$ & 4.1 & 2.26 & 0.89 & 5.85 & 1.27 & 1.78 & 1.06 & 4.39 & 1.00 & 0.84 & 0.44 & 2.54 & 0.41 & 0.65 & 0.803 & 1.12 \\
\hline $\mathrm{Nb}(\mu \mathrm{g} / \mathrm{g})$ & 10 & 11.0 & 8.8 & 13.2 & 1.1 & 11.6 & 8.5 & 13.4 & 1.5 & 13.3 & 5.0 & 27.7 & 3.8 & 10.0 & 0.862 & 1.10 \\
\hline $\mathrm{Nd}(\mu \mathrm{g} / \mathrm{g})$ & 39.9 & 23.0 & 17.3 & 29.1 & 2.4 & 29.4 & 25.3 & 47.3 & 6.5 & 35.2 & 22.1 & 58.3 & 7.3 & 32.4 & 0.952 & 1.08 \\
\hline $\mathrm{Ni}(\mu \mathrm{g} / \mathrm{g})$ & 29 & 25.9 & 14.5 & 60.3 & 7.7 & 30.4 & 20.5 & 52.2 & 9.3 & 34.9 & 17.0 & 76.5 & 12.1 & 32.0 & 0.949 & 1.12 \\
\hline $\mathrm{Pb}(\mu \mathrm{g} / \mathrm{g})$ & 25.4 & 68.8 & 35.0 & 134.3 & 22.0 & 85.3 & 46.4 & 221.2 & 57.9 & 30.9 & 11.7 & 164.5 & 24.0 & 23.8 & 0.966 & 1.12 \\
\hline $\mathrm{Rb}(\mu \mathrm{g} / \mathrm{g})$ & 99 & 56.2 & 31.2 & 68.3 & 7.8 & 66.8 & 55.7 & 85.2 & 9.5 & 74.0 & 19.4 & 101.0 & 15.2 & 49.6 & 0.836 & 1.07 \\
\hline $\mathrm{Sb}(\mu \mathrm{g} / \mathrm{g})$ & 1.1 & 6.07 & 1.63 & 26.33 & 5.20 & 2.72 & 1.46 & 7.63 & 1.82 & 0.75 & 0.27 & 1.65 & 0.22 & 0.34 & 0.934 & 1.22 \\
\hline $\operatorname{Sc}(\mu \mathrm{g} / \mathrm{g})$ & 11.44 & 8.2 & 7.0 & 9.7 & 0.6 & 10.4 & 9.2 & 13.1 & 1.1 & 11.8 & 8.2 & 18.3 & 2.4 & 8.2 & 0.863 & 1.16 \\
\hline
\end{tabular}




\begin{tabular}{|c|c|c|c|c|c|c|c|c|c|c|c|c|c|c|c|c|}
\hline $\operatorname{Sr}(\mu \mathrm{g} / \mathrm{g})$ & 202 & 323 & 249 & 366 & 32 & 349 & 310 & 386 & 24 & 232 & 143 & 406 & 66 & 435 & 0.909 & 1.07 \\
\hline $\operatorname{Ti}(\mu \mathrm{g} / \mathrm{g})$ & 4300 & 3601 & 3035 & 4906 & 411 & 3713 & 3386 & 4111 & 237 & 4376 & 2016 & 11067 & 1434 & 2679 & 0.881 & 1.11 \\
\hline $\mathrm{Tl}(\mu \mathrm{g} / \mathrm{g})$ & 0.461 & 0.43 & 0.33 & 0.57 & 0.05 & 0.58 & 0.34 & 1.02 & 0.24 & 0.48 & 0.27 & 0.74 & 0.13 & 0.21 & 0.859 & 1.11 \\
\hline $\mathrm{Y}(\mu \mathrm{g} / \mathrm{g})$ & 24.8 & 20.6 & 16.2 & 23.9 & 1.8 & 23.6 & 19.9 & 27.6 & 2.4 & 25.6 & 9.6 & 32.7 & 4.3 & 18.8 & 0.971 & 1.18 \\
\hline $\mathrm{Zn}(\mu \mathrm{g} / \mathrm{g})$ & 102.6 & 264 & 123 & 444 & 88 & 318 & 175 & 977 & 240 & 98 & 64 & 168 & 27 & 92 & 0.942 & 1.07 \\
\hline $\mathrm{Al}(\%)$ & 6.99 & 5.43 & 4.97 & 6.03 & 0.24 & 5.10 & 4.36 & 5.89 & 0.46 & 6.46 & 5.11 & 8.04 & 0.75 & 5.47 & 0.856 & 1.17 \\
\hline $\mathrm{Fe}(\%)$ & 2.97 & 2.87 & 1.96 & 4.05 & 0.44 & 4.54 & 3.23 & 9.49 & 1.90 & 4.04 & 2.60 & 7.20 & 1.06 & 2.81 & 0.972 & 1.06 \\
\hline $\operatorname{Mg} \quad(\%)$ & 1.27 & 1.90 & 0.89 & 3.27 & 0.45 & 1.83 & 1.03 & 2.57 & 0.43 & 1.27 & 0.47 & 2.26 & 0.44 & 1.20 & 0.956 & 1.07 \\
\hline $\mathrm{Ca}(\%)$ & 1.52 & 5.26 & 2.76 & 7.75 & 0.94 & 4.75 & 2.97 & 5.96 & 1.03 & 1.85 & 0.32 & 4.84 & 0.92 & 11.35 & 0.925 & 1.04 \\
\hline $\mathrm{Na}(\%)$ & 1.31 & 1.58 & 1.22 & 1.75 & 0.14 & 1.96 & 1.39 & 3.19 & 0.63 & 1.55 & 0.18 & 2.65 & 0.35 & 1.77 & 0.949 & 1.04 \\
\hline $\mathrm{K}(\%)$ & 1.93 & 1.67 & 1.39 & 1.86 & 0.12 & 1.60 & 1.20 & 2.09 & 0.24 & 1.97 & 1.47 & 3.06 & 0.29 & 1.84 & 0.945 & 1.02 \\
\hline
\end{tabular}

Note: *The background value of Beijing region (reference: China National Environmental Monitoring Center, 1990) **Recovery rate

has no unit.

Table 5 Potential sources of metals from different industries and vehicles

\begin{tabular}{|c|c|c|c|c|c|c|c|c|c|c|c|c|c|}
\hline Potential sources & $\mathrm{Ba}$ & $\mathrm{Cd}$ & $\mathrm{Cr}$ & $\mathrm{Cu}$ & $\mathrm{Pb}$ & $\mathrm{Sb}$ & $\mathrm{Sr}$ & $\mathrm{Zn}$ & $\mathrm{Al}$ & $\mathrm{Fe}$ & $\mathrm{Ca}$ & $\mathrm{Hg}$ & $\mathrm{Mg}$ \\
\hline Braking system & $x$ & - & - & $x$ & - & $x$ & - & - & - & $x$ & - & - & - \\
\hline Automobile metal part wear & - & - & $x$ & - & - & - & - & - & $x$ & $x$ & - & - & $x$ \\
\hline
\end{tabular}




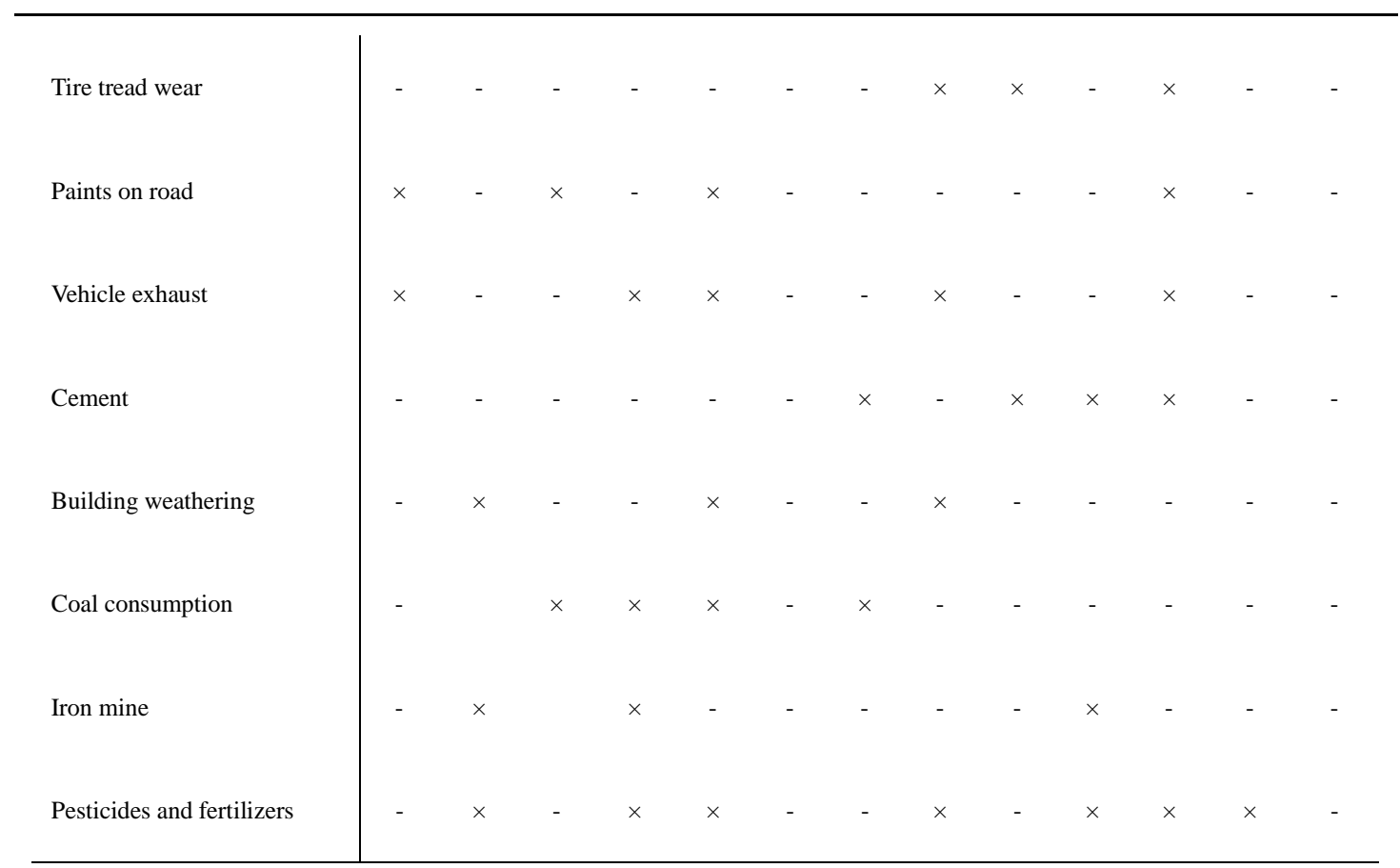

*References: Li et al., 2001; Adachi and Tainosho, 2004; Widory et al., 2010; Charlesworth et al., 2011.

Table 6 Lead isotope ratios of four end-members

\begin{tabular}{|c|c|c|c|c|}
\hline & $(207 / 206)_{j}$ & $(204 / 206)_{j}$ & $(208 / 206)_{j}$ & References \\
\hline Background $(j=1)$ & 0.9060 & 0.0591 & 2.1416 & Zhang, 1989; Basu et al., 1991; Zhu, 1995 \\
\hline Coal $(j=2)$ & 0.8551 & 0.0552 & 2.1007 & Mukai et al., 2001; Widory et al., 2010 \\
\hline Vehicle exhaust $(\mathrm{j}=3$ ) & 0.8643 & 0.0552 & 2.1116 & Zhu et al., 2001; Gao et al., 2004; Chen et al., 2005; Tan et al., 2006 \\
\hline Industry $(\mathrm{j}=4)$ & 0.8748 & 0.0562 & 2.1961 & Zhu et al., 2003; Widory et al., 2010 \\
\hline
\end{tabular}

